\title{
ANALISIS POLA KONFIGURASI RUANG TERBUKA KOTA DENGAN PENGGUNAAN METODA SPACE SYNTAX SEBAGAI SPATIAL LOGIC DAN SPACE USE
}

\author{
Muhammad Fajri Romdhoni', ${ }^{*}$ Priemadella ${ }^{2}$, Adam Fitriawijaya ${ }^{3}$ \\ ${ }^{1}$ Program Studi Teknik Arsitektur, Fakultas Teknik, Universitas Sriwijaya, Inderalaya \\ *muhammadfajriromdhoni@unsri.ac.id
}

\begin{abstract}
ABSTRAK. Pengembangan kota Palembang terus berkembang sejak adanya kegiatan Pekan Olah Raga Nasional PON dan juga SEA Games yang dilaksanakan di kota Palembang. Saat ini Palembang terus berbenah diri dengan menyosong dilaksanakannya kegiatan olah raga Asean Games di tahun 2018 ini. Berbagai pengembangan fisik kota dari dibangunan jaringan LRT (light rapid transit), pembangunan pusat perbelanjaan dan juga hotel-hotel baru hingga peremajaan dan pembangunan ruang terbuka untuk menampung kegiatan spatial dan kegiatan baik masyarakat kota Palembang itu sendiri ataupun untuk kepentingan pariwisata kota Palembang. Perkembangan ruang kota tersebut dirasakan peneliti dikerjakan dengan terburu-buru dan tidak disertai dengan perencanaan yang matang, sehingga menghasilkan produk yang tidak maksimal. Penelitian ini bertujuan untuk meneliti konfigurasi ruang terbuka yang ada di kota Palembang, dan lokasi dari penelitian tersebut adalah ruang terbuka yang sangat terkenal di kota palembang yaitu ruang terbuka kawasan Benteng Kuto Besak. Di dalam ruang terbuka BKB tersebut terdapat beberapa elemen yang tidak sesuai dengan konfigurasi ruang terbuka yang baik, dan ditinjau dari analisis space syntax yang berguna untuk mengukur kualitas spatial, terlihat bahwa di ruang terbuka BKB tersebut tercipta beberapa ruangruang mati dan elemen di kawasan tersebut yang cenderung melemahkan kualitas spatial yang ada. Tujuan dari penelitian ini adalah untuk melihat ruang gerak yang wajar di ruang terbuka BKB, di dalam arsitektur hal tersebut dikenal dengan istilah spatial logic yang berguna untuk melihat arah pengembangan ruang terbuka agar dapat dimanfaatkan secara maksimal bagi space use konfigurasi ruang terbuka kota Palembang.
\end{abstract}

Kata kunci: ruang terbuka, Benteng Kuto Besak, space syntax, spatial logic, space use

\begin{abstract}
The development of Palembang city has arisen since the National Sporting Event known as PON and also the Southeast Asian games known as SEA games thas is being held in the town. Nowadays the city has transformed itself and constantly changing for the preparation to hold another international sporting event known as Asian games in the year 2018. There are many development that is being done to the city from the building of the new infrastructure of Light Rapid Transit rails across the city and also the development of new shopping malls and even new hotels to the development of the towns open space that is a spatial spot that holds the public event and also has the particular needs to be developed to support the cities tourism. The researcher felt that development that is being done in the city is done carelessly and without careful planning and produces poor spatial products. This research purpose is to analyze the open space configuration carefully and the place that the research is being carried out is a well known open space in Palembang which is the open space of Benteng Kuto Besak, or that is well known as BKB. The elements inside BKB is not appropriate to the spatial configuration of good public space, and through the space syntax analysis to see the spatial quality we can see that there are dead spaces throughout the $B K B$ area and the spatial elements inside the BKB are responsible for them. The purpose of this research is to understand the natural flow of space and to see the spatial logic that is intended for the BKB space. Through the spatial logic, we can also see the best space use designed for the BKB open space configuration pattern in Palembang.
\end{abstract}

Keywords: open space, Benteng Kuto Besak, space syntax, spatial logic, space use

\section{PENDAHULUAN}

Palembang adalah kota tertua di Indonesia dan seiiring dengan perkembangan kota, Palembang pun tidak luput dari perubahan dan transformasi ruang kota. Perubahan tersebut memberikan dampak terhadap wajah kota, karena perubahan pada sebuah kota dapat memunculkan tatanan baru, tapi sering kali justru menghilangkan tatanan lama yang sudah ada. [1,2]. Perkembangan kota Palembang berkembang dengan sangat pesat dan membutuhkan kontrol perencanaan yang baik. Dibutuhkan sebuah pola penataan ruang yang baik sesuai dengan UU no 26 tahun 2007 tentang Penataan Ruang, pasal 6 dinyatakan 
bahwa penataan ruang diselenggarakan dengan memperhatikan (1) kondisi fisik; (2) potensi sumber daya alam, sumber daya manusia, dan sebagainya; (3) geostrategis, geopolitik dan geoekonomi. Disamping itu juga ada ketentuan tentang Ruang terbuka baik hijau dan non hijau (pasal 28); dan pada pasal 29 ayat 2 dinyatakan dengan tegas bahwa ruang terbuka hijau pada wilayah kota proporsi paling sedikit $30 \%$ dari luas wilayah. [3].

Dalam Peraturan Menteri Dalam Negeri No 1 tahun 2007 tentang Penataan Ruang terbuka hijau kawasan perkotaan pasal 1 ayat 1 dinyatakan bahwa ruang terbuka adalah ruang-ruang dalam kota atau wilayah yang lebih luas baik dalam bentuk areal/kawasan maupun dalam bentuk area memanjang / jalur di mana dalam penggunaanya lebih bersifat terbuka yang pada dasarnya tanpa bangunan. Pada pasal 3 dijelaskan fungsi Ruang Terbuka (terutama Ruang terbuka hijau kawasan perkotaan) yaitu (a) pengamanan keberadaan kawasan lindung perkotaan; (b) pengendalian pencemaran dan kerusakan tanah, air dan udara; (c) tempat perlindungan plasma nuftah dan keanekaragaman hayati; (d) pengedali tata air dan (e) sarana estetika kota.

Penelitian Febriati Anwar menyatakan bahwa identitas hunian di Palembang berada di tepian Sungai Musi [4]. Peneltian ini bertujuan untuk memperhatikan kondisi ruang publik di kota Palembang, khususnya Benteng Kuto Besak yang sekarang mengalami transformasi dan perubahan dengan semakin bernilai dan menariknya ruang terbuka yang berada di tepian sungai Musi tersebut. Fokus dari penelitian ini bertujuan untuk melakukan studi terhadap pergerakan manusia di kawasan Benteng Kuto Besak dan bagaimana dampak dari pergerakan kawasan tersebut terhadap penggunaan ruang terbuka yang ada di pelataran Benteng Kuto Besak. Tujuan dari penelitian ini adalah untuk (1) melakukan identifikasi dan karakteristik dari pergerakan manusia; (2) kepadatan dan kumpulan massa dan apa dampaknya terhadap perencanaan spatial; (3) mengembangkan kumpulan massa dengan efektif untuk menunjang penggunaan pada Asean Games 2018; dan (4) menentukkan titik-titik penting pada lokasi agar dapat dimanfaatkan sebagai urban installation untuk menunjang publik space.

Penelitian mengenai pergerakan manusia dan penggunaan ruang serta bagaimana pengaruhnya terhadap tata spatial telah berkembang sejak sepuluh tahun terakhir dengan menggunakan Space Syntax di
University College London dan juga Universitas lainnya di dunia. [5]. Penelitian tersebut merupakan penemuan tentang pola yang terbentuk dari pergerakan pedestrian atau manusia dan juga kendaraan yang sangat berkaitan dengan tata atur spasial dan juga pengaruhnya terhadap visibilitas dan penggunaan ruang terbuka di dalam lingkungan binaan. Dasar penelitian tersebut menjadi langkah untuk melakukan identifikasi dan analisis mengenai hubungan antara tata atur spasial dengan pergerakan massa.

Permasalahan pada pergerakan massa sering terjadi pada waktu yang singkat, sehingga sangat membatasi dalam proses pengamatan. Pergerakan massa pada area Benteng Kuto Besak terjadi dengan adanya berbagai kegiatan yang memanfaatkan ruang terbuka sebagai ruang untuk berbagai kegiatan mulai dari kegiatan festival music, dakwah bersama, kegiatan pasar malam dan berbagai aktivitas lainnya. Berbagai perubahan yang terjadi pada Benteng Kuto Besak yang bersifat temporer dan sementara dengan perencanaan yang berubah-ubah menimbulkan tidak terkontrolnya pergerakan manusia dan terjadinya persinggungan pergerakan sehingga menciptakan suasanya yang ramai dan sangat padat.

Percampuran antara berbagai karakteristik pergerakan memerlukan identifikasi pengguna yang jelas sehingga dapat memberikan rekomendasi penempatan dan pemanfaatan ruang agar dapat digunakan dengan lebih teratur dan maksimal. Pengamatan dan identifikasi terhadap permasalahan ruang dimana massa selalu bergerak dan membentuk kepadatan menciptakan variabel yang sangat kompleks. Dengan adanya kompleksitas tentunya tetap dapat diciptakan sebuah keteraturan dengan menggunakan spatial logic dan melakukan pemetaan terhadap pola pola pergerakan yang dapat digunakan sebagai referensi dan tolak ukur pergerakan massa. Penelitian ini akan melakukan studi komparasi antara observasi dengan penggunaan metoda space syntax sebagai alat komputasi data dan melihat perbandingan antara studi kuantitatif dan pengamatan observasi dan pengukuran data di lapangan.

\section{KAWASAN BENTENG KUTO BESAK}

Benteng Kuto Besak atau kawasan yang lebih dikenal warga kota Paelmbang sebagai BKB merupakan pusat kesultanan Palembang dan pusat kekuasaan tradisional yang mengalami 
proses perubahan dari zaman madya menuju zaman baru di abad ke-19. KUTO artinya kota, puri, benteng yang berasal dari kata sanskerta. Sepanjang tujuh kaki, tembok ini diperkuat dengan bastion (baluarti) dan di bagian dalam masih terdapat tembok dan juga pintu-pintu gerbang yang digunakan sebagai tembok pertahanan benteng. Ukuran dari benteng tersebut memiliki lebar 290 meter dan panjang 180 meter. Di bagian dalam dari benteng tersebut dahulu merupakan kraton dalem tempat kediaman raja dan kemudian erubah fungsi menjadi benteng pada saat peperangan melawan penjajah di tahun 1819 dimana terdapaat meriam diatas dinding benteng kuto besak.

Benteng Kuto Besak merupakan daerah keraton keempat dari kesultanan Palembang. Pada awalnya keraton kesultanan Palembang bernama Kuto Gawang dan terletak di lokasi yang sekarang dijadikan pabrik pupuk Sriwijaya. Pada tahun 1651 ketika bangsa Belanda ingin memegang monopoli perdagangan di Palembang, keinginan tersebut ditentang oleh Sultan Palembang, sehingga terjadi perselisihan yang puncaknya adalah penyerbuan terhadap keraton tersebut. Penyerbuan yang disertai pembumihangusan tersebut menyebabkan dipindahkannya pusat pemerintahan ke daerah Beringinjanggut di tepi sungai Tengkuruk, yang saat ini merupakan daerah pasar 16 ilir. Kemudian pada masa pemerintahan Sultan Mahmud Badaruddin I (1724-1758) pusat pemerintahan dipindahkan di lokasi yang saat ini menjadi lokasi Museum Sultan Mahmud Badaruddin II. Selanjutnya pusat pemerintahan Kesultanan Palembang berpindah ke lokasi yang baru, yaitu yang saat ini dikenal dengan nama Kuto Besak. [6].

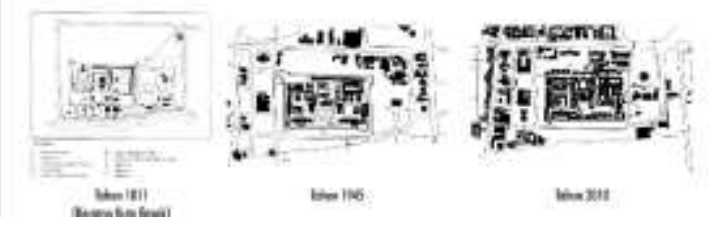

Gambar 1. Perkembangan Kawasan BKB (sumber : dokumentasi pribadi, 2016)

Saat ini keadaan Benteng Kuto Besak telah mengalami beberapa perubahan. Bangunan yang merupakan peninggalan arkeologi dari masa kesultanan Palembang Darussalam adalah tembok keliling sedangkan pintu gerbang utama dan juga beberapa bangunan yang terdapat di dalam lingkungan benteng yang memiliki gaya indis merupakan peninggalan dari masa kolonial Belanda.. Dengan adanya peninggalan tersebut kawasan Benteng Kuto Besak kemudian menjadi kawasan wisata kota Palembang dan menjadi salah satu ruang terbuka kota hingga menjadi venue beberapa kegiatan seperti tempat konser, tempat pengajian akbar, ruang olah raga bagi warga kota Palembang, hingga tempat wisata di kota Palembang.

Tabel 1. Kriteria Benda Cagar Budaya

\begin{tabular}{|c|c|c|}
\hline no & $\begin{array}{l}\text { Kriteria } \\
\text { Budaya } \\
\text { Undang (Undang- } \\
\text { 2010)) }\end{array}$ & $\begin{array}{l}\text { Kondisi Benteng } \\
\text { Kuto Besak }\end{array}$ \\
\hline 1 & $\begin{array}{l}\text { Usia lebih dari } 50 \text { tahun } \\
\text { atau lebih }\end{array}$ & $\begin{array}{l}\text { Dibangun pada } \\
\text { abad ke } 16\end{array}$ \\
\hline 2 & $\begin{array}{l}\text { Mewakili masa gaya } \\
\text { paling singkat berusia } \\
50 \text { (lima puluh) tahun }\end{array}$ & $\begin{array}{l}\text { Gaya bangunan } \\
\text { pencampuran } \\
\text { antara benteng } \\
\text { dan gaya } \\
\text { arsitektur } \\
\text { kolonial indis }\end{array}$ \\
\hline 3 & $\begin{array}{l}\text { Memiliki arti khusus } \\
\text { bagi sejarah, ilmu } \\
\text { pengetahuan, } \\
\text { pendidikan, agama, dan } \\
\text { atau kebudayaan }\end{array}$ & $\begin{array}{l}\text { Digunakan } \\
\text { sebagai pusat } \\
\text { pemerintahan } \\
\text { kesultanan } \\
\text { Palembang } \\
\text { darussalam dan } \\
\text { mempunyai arti } \\
\text { penting bagi } \\
\text { perkembangan } \\
\text { kota Palembang }\end{array}$ \\
\hline 4 & $\begin{array}{l}\text { Memiliki nilai budaya } \\
\text { bagi penguatan } \\
\text { kepribadian bangsa }\end{array}$ & $\begin{array}{l}\text { Miliki nilai } \\
\text { budaya yang } \\
\text { tinggi dan } \\
\text { sebagai } \\
\text { peninggalan } \\
\text { pemerintahan } \\
\text { kesultanan } \\
\text { Palembang. }\end{array}$ \\
\hline
\end{tabular}

(Sumber : analisis pribadi, 2016)

Melihat kondisi Benteng Kuto Besak yang mengacu pada undang-undang cagar budaya dan proses pelestarian pasal 53 ayat $1 \mathrm{UU}$ no11 tahun 2010 menjadikan Benteng Kuto Besak sebagai kawasan yang dilindungi dan membutuhkan perencangan pengembangan secara hati-hati [7]. Oleh karena itu pengembangan kawasan BKB membutuhkan kajian yang mendalam baik dalam merencanakan bangunan baru di kawasan tersebut ataupun mengembangkan penggunaan dan pemanfaatan ruang terbuka yang ada di kawasan BKB tersebut. 


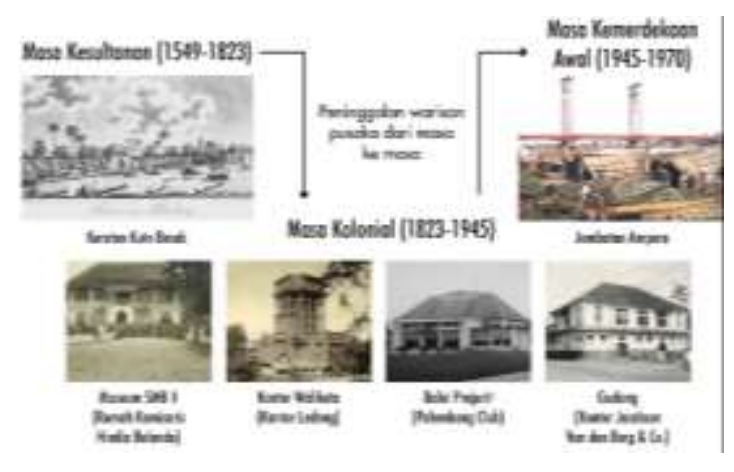

Gambar 2. Bangunan Di Sekitar Kawasan BKB (sumber : dokumentasi pribadi, 2016)

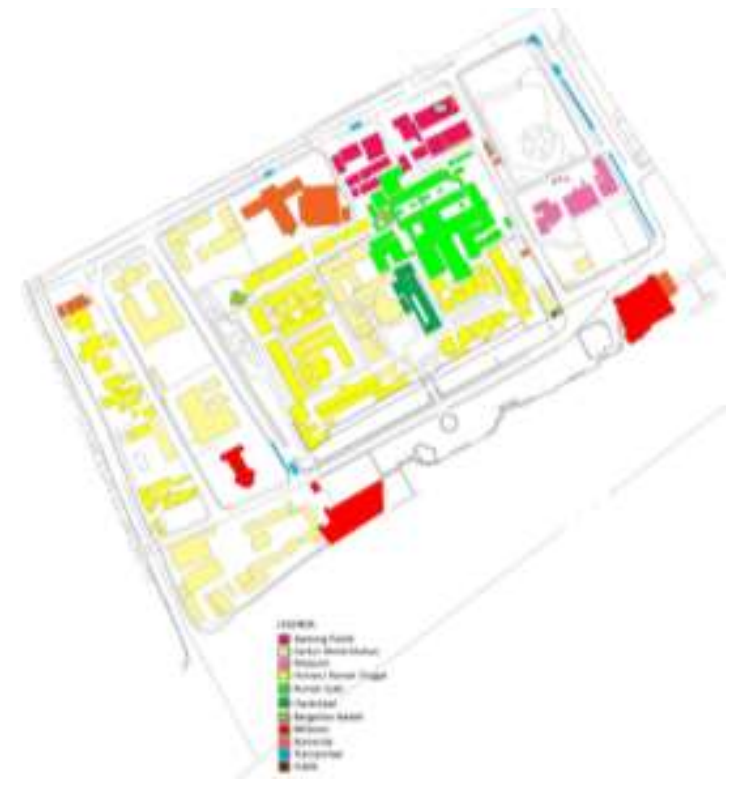

Gambar 3. Identifikasi Bangunan di Sekitar Kawasan BKB

(sumber : dokumentasi pribadi, 2016)

Saat ini kawasan Benteng Kuto Besak terus mengalami perbaikan dan pembangunan. Dilihat dari Land Use kawasan tersebut bagian dalam Benteng Kuto Besak di dominasi oleh fungsi hunian dan juga kantor pemerintahan milik TNI. Melihat kondisi tersebut bagian dalam benteng penggunaan ruang sangat tidak optimal dan tidak terencana dengan baik, namun bagian luar tapak mulai di kelilingi oleh area komersil seperti Center point dan restoran terapung yang merupakan komersil kuliner menunjang kawasan tersebut sebagai destinasi wisata kota Palembang

Pada Penelitian ini difokuskan kepada perencanaan kawasan ruang terbuka Benteng Kuto Besak. Saat penelitian ini dilakukan, pemerinatah kota Palembang menambahkan fasilitas wisata baru berupa patung belido yang menghadap sungai Musi.
Tabel 2. Kriteria Benda Cagar Budaya

\begin{tabular}{|c|c|}
\hline $\begin{array}{l}\text { Aksesibilitas pejalan } \\
\text { kaki }\end{array}$ & $\begin{array}{l}\text { Aksesibilitas } \\
\text { kendaraan }\end{array}$ \\
\hline$i$ & \\
\hline $\begin{array}{l}\text { Berdasarkan pengamatan } \\
\text { terdapat banyak akses } \\
\text { untuk pencapaaian } \\
\text { pejalan kaki, baik dari } \\
\text { kawasan museum SMB II } \\
\text { dan juga pencapaian dari } \\
\text { jalan sekanak. Pejalan } \\
\text { kaki juga dapat meng } \\
\text { akses kawasan tersebut } \\
\text { melalui perahu pelabuhan } \\
\text { yang tersedia di BKB }\end{array}$ & $\begin{array}{lr}\text { Enterance } & \text { dan juga } \\
\text { exit pada kawasan } \\
\text { tersebut ditunjukkan } \\
\text { dengan arah panah } \\
\text { sebagai indikator } \\
\text { enterance dan garis } \\
\text { putus-putus sebagai } \\
\text { area exit jawasan } \\
\text { tersebut. }\end{array}$ \\
\hline
\end{tabular}

(Sumber : analisis pribadi, 2016)

\section{SPACE SYNTAX}

Penelitian ini bertujuan untuk melakukan perencanaan jangka panjang yang terintegrasi dari kawasan sepanjang sungai musi dan pengembangan kota Palembang untuk masa yang akan datang dengan melakukan penerapan space syntax sebagai metoda untuk melakukan analisis matematis. Space syntax adalah sebuah metoda untuk melakukan pengamatan dan penyusunan ruang agar menghasilkan integrasi ruang, baik secara visual maupun pergerakan secara optimal. Penerapan Space Syntax dilakukan dengan melakukan perbandingan antara pengamatan observasi sebagai metoda dengan dasar kualitatif dan juga dengan menggunakan UCL depthmap untuk menghasilkan kalkulasi hubungan ruang dan integrasi antara ruang pengamatan baik dalam skala ruang pedestrian ataupun jalan di dalam sebuah kota. Penelitian yang menggunakan mixed method antara kualitatif dan kuantitatif uini bertujuan agar penelitian ini dapat bersifat objektif dan menghasilkan rekomendasi terbaik. Riset kualitatif sangat tepat digunakan untuk menjelaskan sebuah fenomena [8], sedangan riset kuantitatif merupakan cara bagi peneliti untuk menghasilkan klaim secara positif untuk mengembangkan ilmu pengetahuan [9].

Space syntax adalah sebuah metoda untuk menjelaskan dan menganalisis hubungan antara void pada ruang terbukadan hubungan yang terbentuk terhadap pola ruang yang ada. Menurut The social logic of space, space syntax adalah sebuah teknik untuk melakukan 
visualisasi, pengukuran dan juga perhitungan dari konfigurasi ruang dan menghasilkan analisis serta memberikan definisi terhadap ruang yang terbentuk. [5] Teori space syntax merupakan hubungan antara masyarakat dan susunan struktur pembentuk ruang di dalam teori urban dan pembentukan ruang arsitektural. Pemahaman mengenai teori tersebut menghasilkan dasar penelitian secara analitis untuk menghasilkan studi mengenai ruang terbuka dan ruang publik dalam lingkup : ruang spasial, kehidupan masyarakat, rutinitas pergerakan, pemaknaan ruang, interaksi dan juga konfigurasi ruang. Teori tersebut berkaitan dengan hubungan antara pergerakan pedestrian dan juga konfigurasi ruang publik [10].

Terdapat tiga cara dalam penggunaan metoda space syntax dalam UCL depthmap v.10.15.00r yaitu sebagai berikut :

1. Convex space adalah ruang yang terbentuk dari volume dan tata letak ruang. Convex space digunakan untuk melihat data numerik tentang hubungan ruang

2. Axial space merupakan garis ratio yang merupakan representasi dari perhitungan pejalan kaki. Penggunaan axial space dapat dihitung dengan memperlihatkan pergerakan dan sirkulasi terhadap ruang

3. Isovist, merupakan ruang yang dihasilkan dari hubungan ruang berdasarkan titik tertentu di dalam ruang. Isovist digunakan untuk melihat zona dan ruang yang lebih dominan integrasi terhadap ruang yang lain.

Menurut Stonor terdapat tiga langkah yang perlu dilakukan dalam melakukan analisis terhadap teori ruang pada Space Syntax menggunakan UCL depthmap yaitu sebagai berikut [11]:

1. Axial / Segment analysis. Adalah cara untuk melakukan analisis terhadap ruang dengan skala yang besar seperti jalan, kawasan ataupun skala kota. Axial analisis merupakan hubungan antara sirkulasi di dalam sebuah ruang kota dengan melakukan kajian terhadap pergerakan, nilai kawasan dan juga akitivitas sosial. Perbedaan antara axial dan segment adalah dari tata cara penggunaan pengukuran matrix dan pengukuran segmen dengan memperhatikan depth / kedalaman.
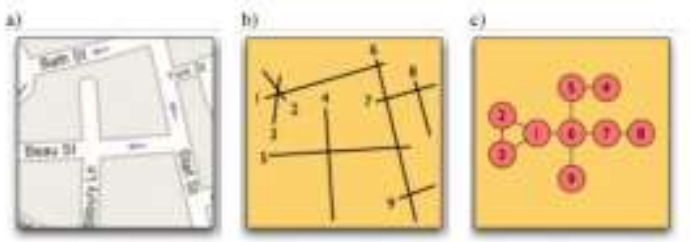

Gambar 4. Representasi graph, axial dan city map (sumber : introduction to space syntax)

Sebuah axial map di transformasikan menjadi simbol grafis / graph yang diwakilkan dalam garis axial dan membentuk node (persilangan), sehingga membuat sambungan dari node tersebut. Grafik di atas merepresentasikan peta secara intusi dimana jalan dan persilangan sebagai nodes dan streets. Space Syntax berfungsi secara bertolak belakang dimana jalan menjadi nodes dan persilangan menjadi links. Secara teori tersebut untuk memperhitungkan jalan sebagai representasi garis dan satu buah persilangan pada peta. Hal tersebut memberikan kemudahan dalam memperhitungkan hirarki terhadap masing masing jalan dengan meilihat hubungan jalan terhadap jalan lainnya, dimana jalan yang memiliki banyak persilangan menunjukkan keutamaan dan konektivitas jalan tersebut.

2. VGA (Visual Graph Analysis) pada skala yng lebih kecil seperti pada ruang bangunan. Didalam VGA terdapat analisis isovist untuk menentukan titik tertentu di dalam ruang sebagai perhitungan pergerakan pejalan kaki dan juga interaksi sosial. Didalam VGA juga kita dapat melakukan perhitungan integrasi jalan dengan memperhatikan pergerakan dan semakin sedikit nya perubahan arah terhadap jalan akan menghasilkan ruang yang semakin terintegrasi dengan baik. Semakin tidak terintegrasinya sebuah ruang akan menghasilkan ruang yang lebih terisolasi dan membutuhkan perubahan agar menghasilkan ruang yang lebih terintegrasi. Penggunaan VGA ini juga dikenal dengan sistem metrik dengan melakukan kalkulasi terhadap jarak dan integrasi ruang.

Di dalam sistem metrik terdapat beberapa istilah yang akan digunakan untuk menentukan hubungan antara grafik dan hasil Space Syntax. Teori yang sering digunakan di dalam perhitungan metrik adalah (1) integration; (2) connectivity; dan (3) choice.

Integration di dalam metoda tersebut adalah untuk memperhitungkan jarak 
antara ruang dimana sebuah ruang yang memiliki jarak hubungan ruang yang pendek akan menghasilkan ruang yang lebih terintegrasi jika dibandingkan dengan ruang yang memiliki jarak yang berjauhan dengan ruang lainnya.

Connectivity merupakan metoda untuk melihat derajat hubungan antara ruang yang diperlihatkan dari persilangan antara ruang. Ruang yang memiliki konektivitas ruang yang baik adalah ruang yang memiliki persinggungan ruang yang paling banyak terhadap ruang lainnya sehingga memiliki derajat hirarki ruang yang lebih utama.

Choice merupakan pilihan yang akan diambil terhadap sebuah ruang dengan menunjukkan jarak terdekat di dalam garis visual sebuah ruang. Metoda tersebut sangat berguna untuk melihat pilihan pergerakan massa yang sering kali mengambil jarak terdekat untuk menempuh destinasi ruang.

Tabel 3. Komponen Space Syntax

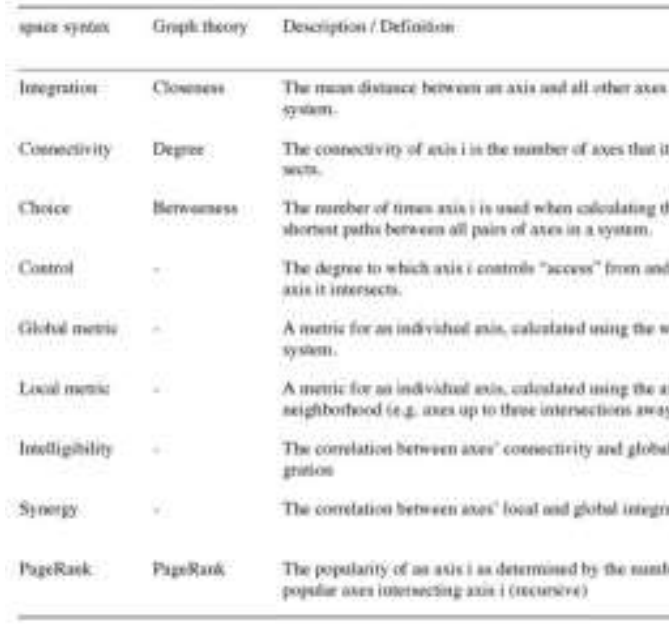

Sumber : introduction to space syntax

3. Agent Analysis merupakan alat yang digunakan di dalam space syntax dengan melakukan simulasi dari pergerakan manusia di dalam ruang. Hal tersebut merupakan metoda gabungan dari axial analysis dan Visual graph analysis dengan menggunakan model manusia untuk memberikan kalkulasi pergerakan manusia di dalam ruang penelitian.

Ruang terbuka adalah salah satu aspek dalam lingkungan perkotaan yang terpenting di dalam kehidupan sehari-hari manusia yang hidup di lingkungan tersebut, namun seringkali ruang terbuka ini diabaikan dalam pemikiran arsitektur dan lingkungan buatan. [12]. Ruang terbuka mempunyai kaitan dengan lansekap sedangkan elemen lansekap terdiri dari elemen hardscape, serta elemen softscaper. Ruang terbuka bisa berbentuk lapangan, jalan, sempadan sungai, green belt, taman dan sebagainya. [13]

Fungsi ruang terbuka pada kawasan tidak hanya sekedar fisik sebuah ruangan tidak terbangun, namun mempunyai peran penting dalam kehidupan sehari-hari sebagai sarana/tempat untuk melepas kepenatan warga sekitarnya.[12]. Sebuah kota dikatakan sebagai kota yang sustainable [14], yang terkait dengan ruang terbuka, jika memenuhi kriteria berikut :

- Kota yang 'hijau' yang meminimalisir dampak lingkungan, terutama terkait dengan keseimbangan antara ruang terbangun dan ruang terbuka serta infrastuktur yang mendukungnya;

- Kota yang mendorong interaksi antar komunitas warga kotanya.

Dengan perkembangan kota yang sangat pesat dan perubahan ruang kota yang seringkali dilakukan secara instan, dibutuhkan perencanaan jangka panjang dan simulasi terhadap ruang kota yang sudah ada. Dengan dasar pemikiran Benteng Kuto Besak yang menarik para investor seperti adanya rencana pemerintah untuk membangun sebuah tugu "Iwak Belida" yang mendapatkan reaksi dari pemerhati kota dan juga pemerhati heritage sehingga menimbulkan polemik yang berkepanjangan terhadap kualitas ruang kota tersebut. Dengan adanya anlisis mengenai pergerakan yang ada di dalam ruang kota tersebut diharapkan penelitian ini dapat memberikan kontribusi di bidang eksistensi ruang tersebut dan memberikan pilihan terhadap rencana pengembangan yang akan di lakukan di masa yang akan datang.

\section{METODOLOGI}

Tahapan penelitian ini terbagi dalam empat tahapan. Tahapan pertama : pengumpulan data eksisting dengan pendataan kondisi aktual di lokasi penelitian Benteng Kuto Besak Palembang. Pengumpulan data dilakukan secara bertahap dan dalam waktu yang berbeda pada hari kerja dan juga pada akhir pekan untuk melihat perubahan dinamika penggunaan ruang terbuka tersebut.

Tahapan kedua : persiapan analisis dengan melakukan penggambaran ulang dari peta / 
foto udara agar mampu di baca dalam tahapan analisis.

Tahapan ketiga : analisis. Pada tahapan ini menggunakan teknik space syntax dengan menggunakan software Depthmap $x-0.50$. Teknik analisis space syntax dikembangkan berdasarkan teori the social logic of space [5]. Teori ini kemudian dikembangkan ke dalam sebuah program komputer sebagai alat untuk menganalisis space syntax dengan presentasi grafik (hillier, space is the machine, 2007 hal 1). Teknik analisis ini berdasarkan pengamatan lingkungan dengan mengamati gerak langkah pejalan kaku dalam berbagai bentuk tata letak kerangka garis (grid layout) dimana tata letak tersebut ditentukan oleh susunan dari kerangka garis (grid). Gerak langkah tersebut timbul karena berbagai faktor dan salah satunya adah daya tarik (attractors). Daya tarik inilah yang selanjutnya dilihat sebagai sesuatu yang menentukan gerak langkah dari pejalan kaki (pedestrian movement). Dalam skala yang lebih besar yaitu dalam skala kawasan / kota, pola kerangka garis tersebut mempunyai arti penting dan kedalaman tiap-tiap jalan dihitung dan dapat dilihat perbedaan kedalaman jalan yang satu dengan yang lain.

Dengan UCL Depthmap $x-0.50$ dapat menghasilkan perbedaan kedalaman analisis dengan memberikan tampilan spektrum warna merah hingga biru dimana warna merah mengindikasikan area yang menerima pergerakan terbanyak dan paling banyak terintegrasi dengan ruang ataupun jalan yang lain. Sedangkan warna biru mengindikasikan area yang paling sedikit menerima pergerakan dan juga paling sedikit integrasi dengan ruang ataupun jalan yang lain. Dalam penelitian ini dilakukan dua analisis space syntax yaitu dengan membuat grafik axial dan juga grafik visibility / visual study. Grafik axial bertujuan untuk memberikan reprentasi dari struktur aksesibilitas yang terus menerus terhadap ruang terbuka dan grafik visibility menganalisis jangkauan suatu titik dalam ruang spasial yang diukur dari kemampuan visual ruang tersebut terhadap ruang lain.

Tahapan keempat : interpretasi hasil analisis. Tahapan ini melakukan perbandingan antara hasil analisis dan melakukan kajian atas hasil tersebut. Pada tahapan ini digunakan metoda analisis deskripsi komparatif. Metoda analisis ini dilakukan dengan mendesskripsikan apa adanya hasil analisis, kemudian melakukan pembandingan dalam konteks ruang terbuka urban pada kawasan BKB tersebut.

\section{ANALISIS OBSERVASI}

Observasi pada kawasan Benteng Kuto Besak dilakukan dengan cara pengamatan langsung pada hari biasa dan hari akhir pekan serta dilakukan juga pengamatan dengan drone untuk mendapatkan gambaran ruang secara aktual dari kawasan BKB.

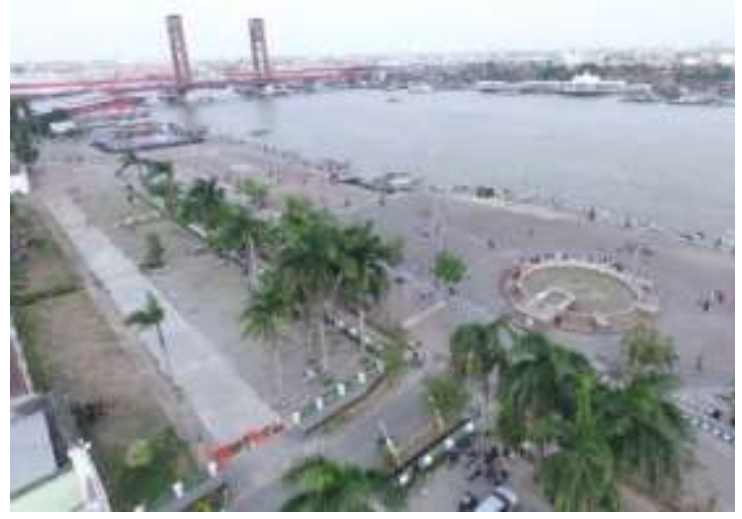

Gambar 5. Representasi Graph,Axial Dan City Map

(sumber : dokumentasi pribadi, 2017)

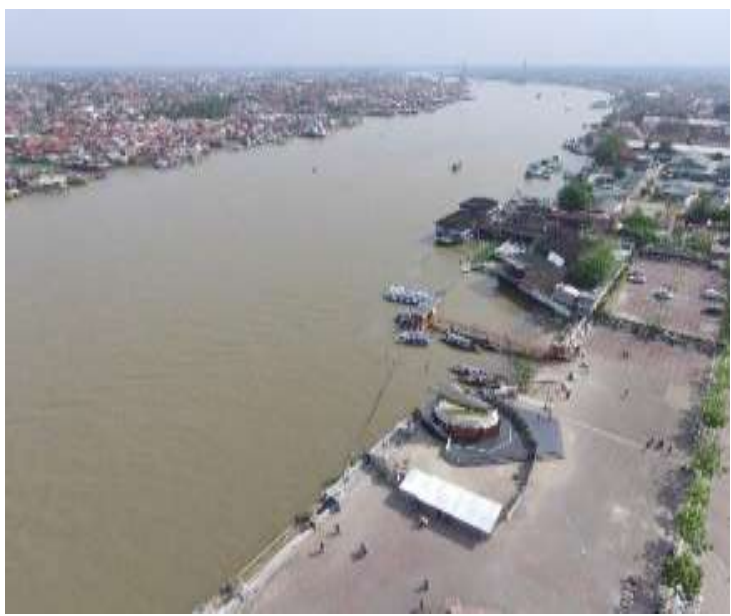

Gambar 6. Representasi Graph, Axial Dan City Map

(sumber : dokumentasi pribadi, 2017)

Pengamatan langsung dilakukan dengan mengambil data crowd movement dan crowd density untuk melihat pergerakan serta kepadatan pengunjung. Pendataan aksesibilitas untuk melihat titik masuk nya pengunjung, landuse kawasan diidentifikasi terdapat perubahan dan pergerakan pemanfaatan ruang terbuka, baik untuk komersial maupun jasa dan juga dispersal area yang ada di kawasan BKB tersebut untuk menunjukkan titik-titik keluar dari pengunjung . 
Dari observasi awal dapat diamati ruang yang terbentuk di kawasan tersebut cenderung mengikuti adanya kepadatan dan kumpulan kegiatan. Dapat diamati juga bahwa terdapat beberapa ruang mati yang timbul dengan tidak optimalnya pemanfaatan ruang terbuka yang ada, terutama pada titik pertemuan antara pelataran dan juga panggung ataupun tugu dimana terdapat ruang-ruang sempit yang dihindari dan tidak digunakan oleh pengunjung.

\section{Kondisi ruang terbuka BKB}

Ruang terbuka yang terdapat di depan Benteng Kuto Besak memiliki eksisting yang tidak direncanakan dengan baik. Saat ini kawasan BKB tersebut tidak lagi dapat diakses oleh kendaraan dan di tutup pada sisi timur dan sisi barat dari ruang terbuka tersebut dan menyisakan penmbatas jalan serta median jalan yang tidak fungsional dan sesuai dengan kebutuhan ruang terbuka.

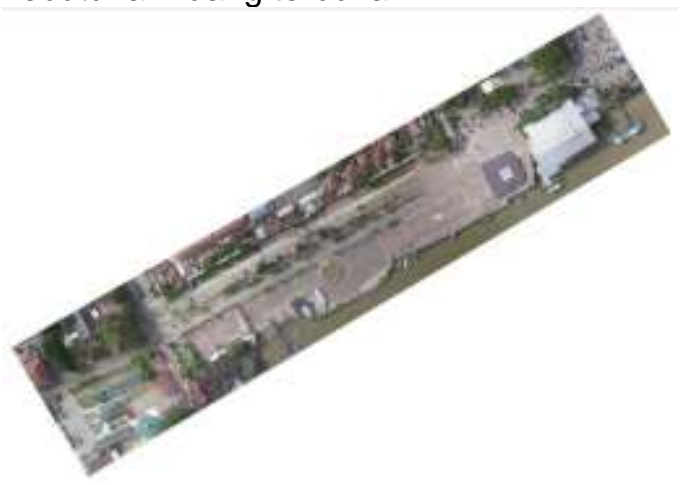

Gambar 7. Eksisting Ruang Terbuka BKB (sumber : dokumentasi pribadi, 2017)

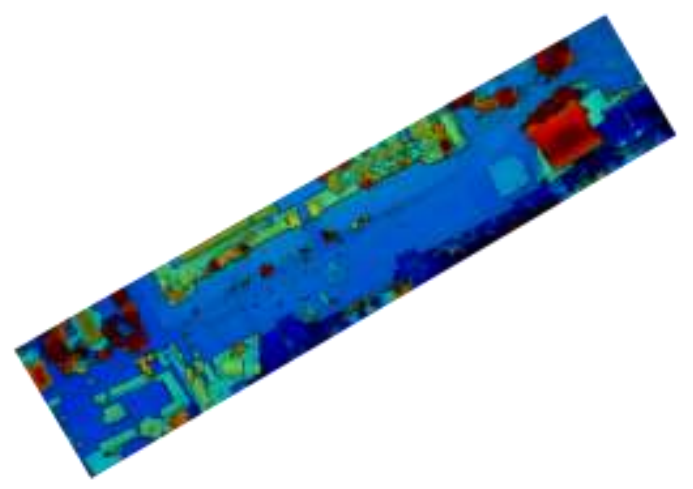

Gambar 8. Peta Elevasi BKB

(sumber : dokumentasi pribadi, 2017)

Pada peta elevasi berikut ini dapat kita lihat bahwa kawasan BKB tersebut memiliki elevasi yang relatif datar dan berada di tepi sungai musi. Elemen yang paling dominan secara elevasi pada kawasan tersebut adalah dermaga poin yang secara geometri dan masa sangat mendominasi kawasan tersebut.

Pada analisis eksisting kawasan Benteng kuto Besak dapat dilihat bahwa ruang terbuka tersebut memiliki potensi ruang terbuka yang cukup besar dengan posisi ruang yang berada tepat di depan kawasan heritage.

Pada penelitian ini dilakukan metode observasi melihat crowd densityl kepadatan pengunjung, pola dan juga pergerakan yang bertujuan untuk memahami lebih jauh fenomena keadatan pengunjung dan secara efektif untuk memberikan saran dan arahan bagi pemerintah untuk dapat melihat kondisi kepadatan dan melakukan penataan terhadap kepadatan yang ada di ruang terbuka tersebut. Dalam mengumpulkan data penelitian dilakukan dengan metoda quantitative dengan mengambil sample kepadatan dalam hari-hari yang berbeda baik pada hari biasa ataupun pada akhir pekan dan juga peneliti melakukan observasi secara kualitatif dengan melihat ruang terbuka dengan analisis space syntax.

Observasi kuantitatif dilakukan untuk melihat secara detail pandangan secara lokal dari pengunjung sedangan observasi kualitatif ditujukan untuk melihat bagaimana pergerakan manusia dan penggunaan ruang dan melihat secara global dari kelompok massa / view of the crowd. Yang dimaksud dengan lokal adalah batas terkecil dari penggunaan ruang dan yang dimaksud dengan global adalah skala penggunaan spatial ruang secara urban. Penelitian ini dilakukan dengan menggabungan mix method antara observasi quantitative dan observasi qualitative dengan menggunakan program space syntax untuk menghasilkan kesimpulan dan saran yang dapat digunakan pembuat kebijakan untuk lebih lanjut mengembangkan kawasan Benteng Kuto Besak dengan lebih baik.

\section{Crowd Movement}

Dalam pola crowd movement dapat dilihat bahwa kawasan benteng kuto besak memiliki akses dari sisi timur dan juga akses dari sisi barat. Dan pergerakan manusia terpusat di kawasan ruang terbuka kawasan BKB tersebut. Dengan adanya konsentrasi massa yang cukup banyak menimbulkan adanya kegiatan komersial baik jasa dan barang. 


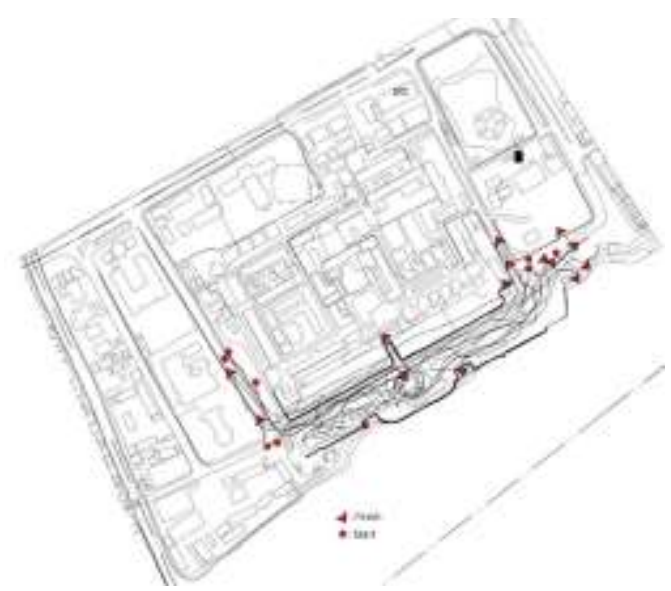

Gambar 9. Pola Crowd Movement BKB (sumber : analisis pribadi, 2017)

Dalam diagramatic representation dapat dilihat bahwa pola pergerakan manusia membentuk area pertemuan / circumference point hal tersebut disebabkan karena destination point dari pengunjung sebagian besar adalah berkumpul di daerah huruf PALEMBANG CITY ataupun mengarah kepada patung "iwak belido".

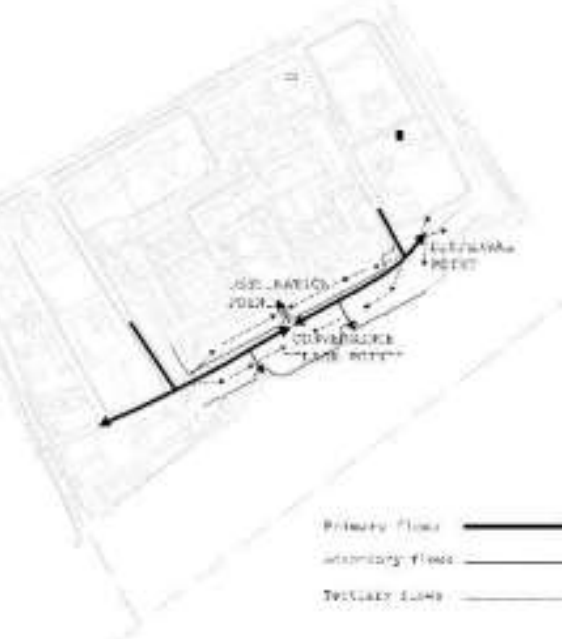

Gambar 10. pola crowd destination BKB (sumber : analisis pribadi, 2017)

\section{Space use}

Perkembangan kawasan Benteng Kuto Besak menimbulkan penggunaan ruang yang sangat beragam. Dari observasi yang dilakukan dalam pengamatan ada beberapa kegiatan antara lain :

- $\quad$ ruang wisata dengan adanya patung iwak belido, logo Palembang city dan juga view yang menghadap jembatan ampera menjadi ruang "selfie" dan view yang sangat baik

- ruang komersial barang baik makanan maupun cendera mata yang terletak di pusat keramaian pada kawasan tersebut

- ruang komersial jasa yang menyediakan atraksi seperti model cosplay transformer hingga marsha and the bear dan juga ada beberapa jasa tato dan lain-lain.

- Adanya ruang penyediaan lahan parkir yang dikelola secara liar dan berkelompok tanpa adanya pengaturan dan standarisasi nominal

Dalam observasi juga dapat dilihat terdapat beberapa ruang "mati" dimana aksesibilitas dan visual yang sangat terbatas. Ruang tersebut tercipta dengan kurang baiknya perencanaan objek wisata yang ada di kawasan BKB tersebut.

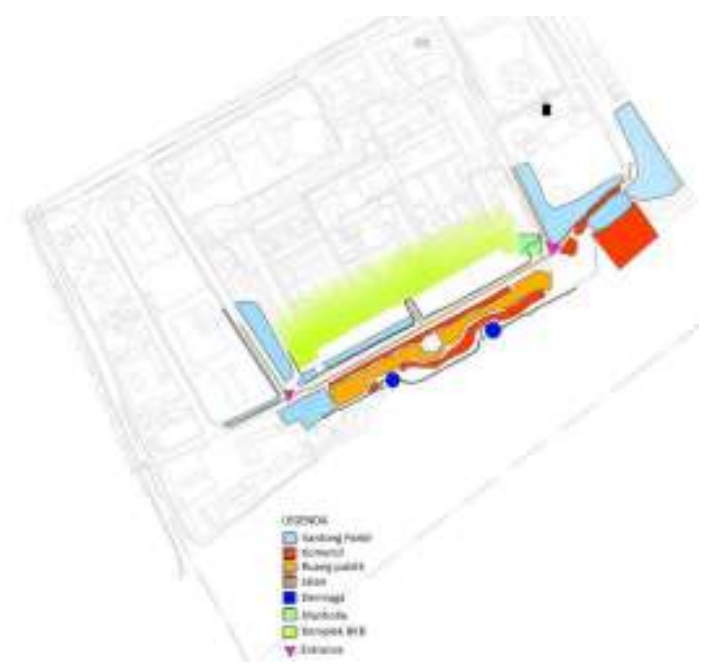

Gambar 11. Space Use Pattern BKB (sumber : analisis pribadi, 2017)

\section{Kepadatan ruang}

Dalam penelitian ini ditinjau juga kepadatan ruang yang ada di BKB tersebut dengan memperhatikan titik titik penting yang ada di kawasan tersebut. Titik itu antara lain

1. Titik masuk kawasan

2. Titik parkir BKB

3. Sidewalk barat kawasan

4. Entrance dermaga

5. Halaman tengan depan BKB

6. Idewalk Timur

7. Titik kantong parkir Timur dan

8. Titik kantong parkir keluar yang berada di sisi timur kawasan BKB. 


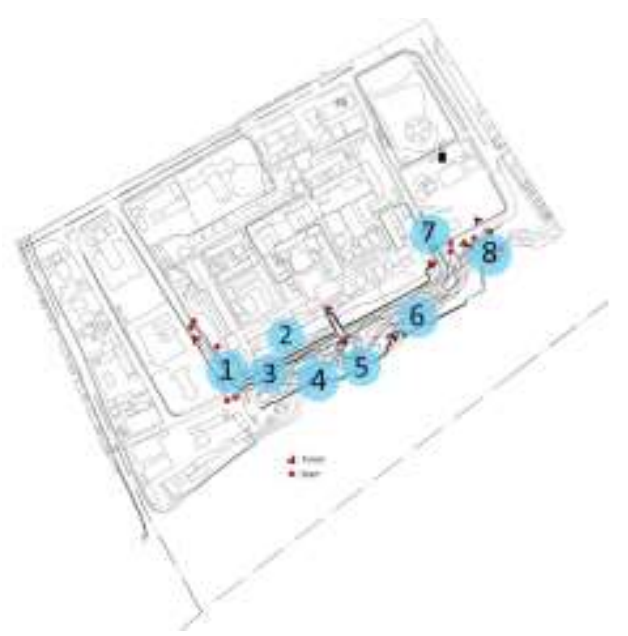

Gambar 12. Pola Kegiatan Kawasan BKB (sumber : analisis pribadi, 2017)

Tabel 4. Kondisi Kepadatan Ruang

\begin{tabular}{|c|c|c|}
\hline no & Foto & Kondisi kepadatan \\
\hline 1 & 6 & 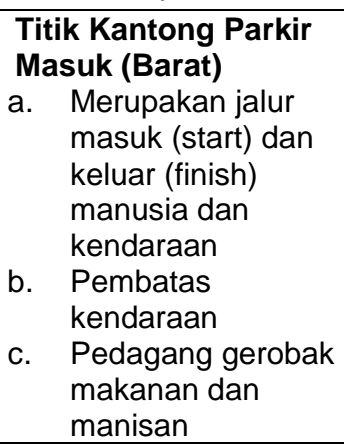 \\
\hline 2 & & 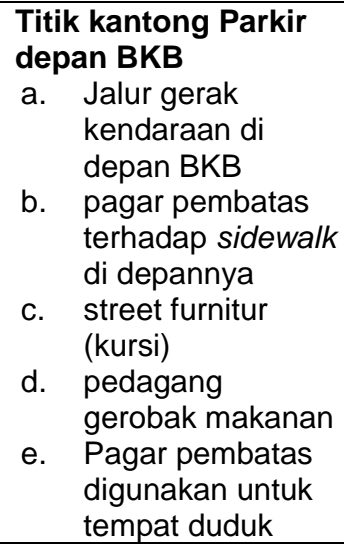 \\
\hline 3 & & $\begin{array}{l}\text { Sidewalk (Barat) } \\
\text { a. Trotoar (sirkulasi } \\
\text { pejalan kaki } \\
\text { b. Terdapat Vegetasi } \\
\text { semak dan pohon } \\
\text { kecil } \\
\text { c. Trotoar digunakan } \\
\text { sebagai tempat } \\
\text { duduk dan } \\
\text { berdagang }\end{array}$ \\
\hline 4 & & $\begin{array}{l}\text { Entrance dermaga } \\
\text { a. Street } \\
\text { furniture(kursi) } \\
\text { b. Terdapat sculpture } \\
\text { ikan Belida } \\
\text { c. Terdapat pedagang }\end{array}$ \\
\hline
\end{tabular}

\begin{tabular}{|c|c|c|}
\hline no & Foto & Kondisi kepadatan \\
\hline & & $\begin{array}{l}\text { jajanan manisan } \\
\text { d. Pedestal Sculpture } \\
\text { digunakan sebagai } \\
\text { tempat duduk }\end{array}$ \\
\hline 5 & & $\begin{array}{l}\text { Halaman tengah } \\
\text { depan BKB } \\
\text { a. Terdapat air } \\
\text { mancur di tengah } \\
\text { b. Terdapat pagar } \\
\text { pembatas sungai } \\
\text { c. Terdapat banyak } \\
\text { pedagang makanan, } \\
\text { mainan, dan } \\
\text { penampilan } \\
\text { komunitas } \\
\text { d. Ramai aktivitas } \\
\text { masyarakat } \\
\text { e. Aktivitas rekreasi: } \\
\text { foto-foto, piknik, dan } \\
\text { berkumpul }\end{array}$ \\
\hline 6 & & 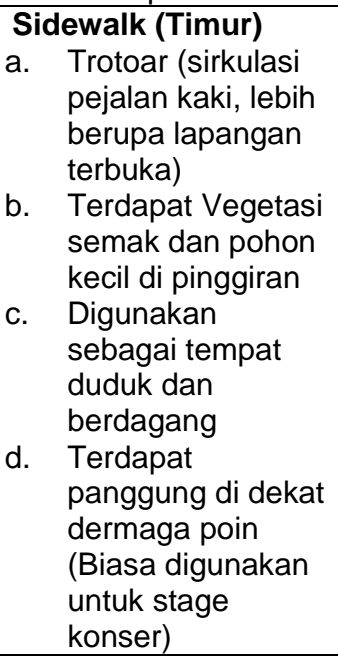 \\
\hline 7 & & \begin{tabular}{ll}
\multicolumn{2}{l}{ Titik Kantong Parkir } \\
Masuk (sisi timur) \\
a. & Merupakan jalur \\
& masuk kendaraan \\
b. & Tedapat Musholla \\
c. & Terdapat portal \\
& pembatas \\
kendaraan \\
d. & Sekitar tempat \\
& parkir terdapat \\
& pedagang \\
& makanan
\end{tabular} \\
\hline 8 & & $\begin{array}{l}\text { Titik Kantong Parkir } \\
\text { Keluar (sisi Timur) } \\
\text { a. } \quad \text { Merupakan jalur } \\
\text { keluar kendaraan } \\
\text { B. } \text { Berada di antara } \\
\text { Museum SMB II } \\
\text { dan restoran } \\
\text { dermaga poin } \\
\text { c. Terdapat } \\
\text { pedagang gerobak } \\
\text { makanan dan } \\
\text { mainan } \\
\end{array}$ \\
\hline
\end{tabular}




\section{ANALISIS SPACE SYNTAX VISIBILITY EKSISTING}

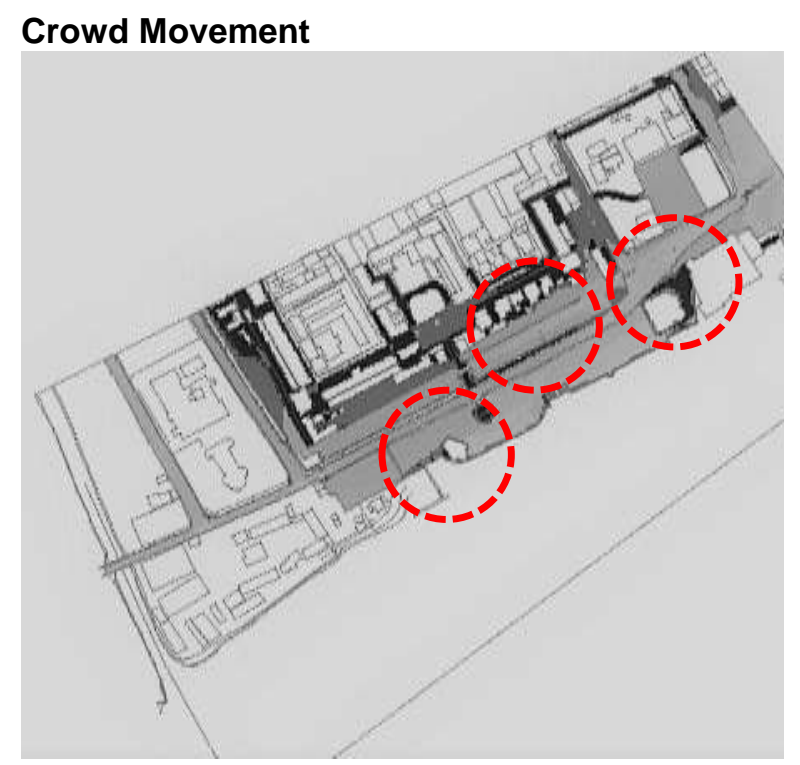

Gambar 13.Crowd Movement

(sumber : analisis pribadi, 2017)

\section{Peta lokasi}

Pada grafik depthmap dapat dilihat dengan jelas, terdapat beberapa ruang yang cukup kontras pada pelataran BKB. Diantara ruang dengan spektrum warna jingga dan kuning terdapat spektrum berwarna biru. Spektrum warna biru tersebut mengindikasikan sedikitnya crowd movement yang ditandai dengan lingkaran berwarna merah.

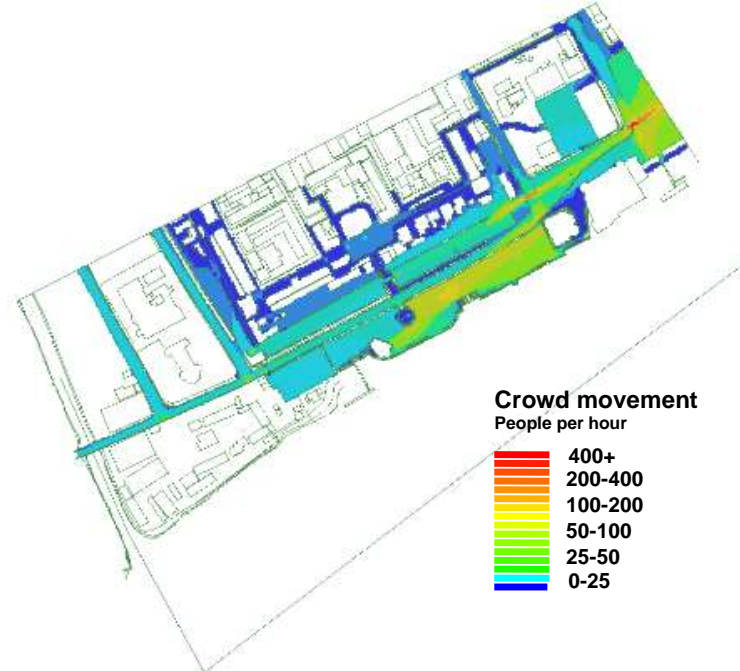

Gambar 14. Analisis Grafik Visual Crowd Movement (sumber : analisis pribadi, 2017)

Analisis grafik visual crowd movement Aksesibilitas pada eksisting kawasan BKB dapat dilihat dari spektrum warna yang terbentuk dimana secara spatial logic dapat dilihat kumpulan crowd movement di dominasi di area pelataran BKB dan juga di kawasan bawah jembatan ampera.

Visibility graph kawasan BKB saat ini cukup merata dengan adanya spektrum warna merah, jingga, dominasi warna kuning dan juga terdapat beberapa warna biru dengan visibility rendah. Integrasi antara ruang cukup baik dan memiliki potensi ruang berkumpul yang sangat besar dengan melihat skala ruang terbuka yang tersedia. Namun dari analisis space syntax tersebut terdapat beberapa elemen ruang yang kurang tepat seperti panggung yang dibuat permanen dan menyisakan sedikit ruang "mati" sehingga tercipta ruang negatif. Beberapa elemen street furniture dan juga pagar menimbulkan adanya pemisah aksesibilitas antara ruang terbuka $B K B$ dengan pelataran $B K B$ tersebut.

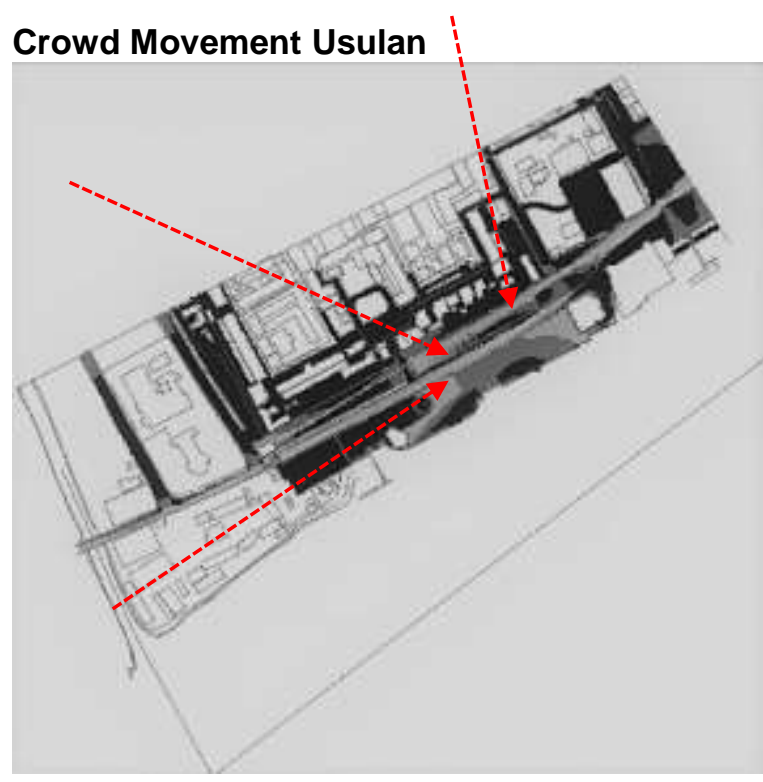

Gambar 15. Crowd Movement Usulan (sumber : analisis pribadi, 2017)

\section{Peta lokasi}

Dengan melihat area yang dominan tersebut, perencanaan dan pengembangan pelataran $\mathrm{BKB}$ harus menyikapi ruang visibility yang tinggi tersebut agar sesuai dengan fungsi utamanya sebagai ruang terbuka kota sehingga tercipta transisi ruang antara visibility tinggi dan visibility rendah dengan baik.

\section{Analisis grafik visual first and second movement}

Spatial accessibility pada pelataran BKB dapat dilihat dari analisis connectivity point first movement dan point second movement. Pada hasil analisis tersebut terlihat jelas spektrum visibility yang dominan berada pada area jalan pelataran BKB. 


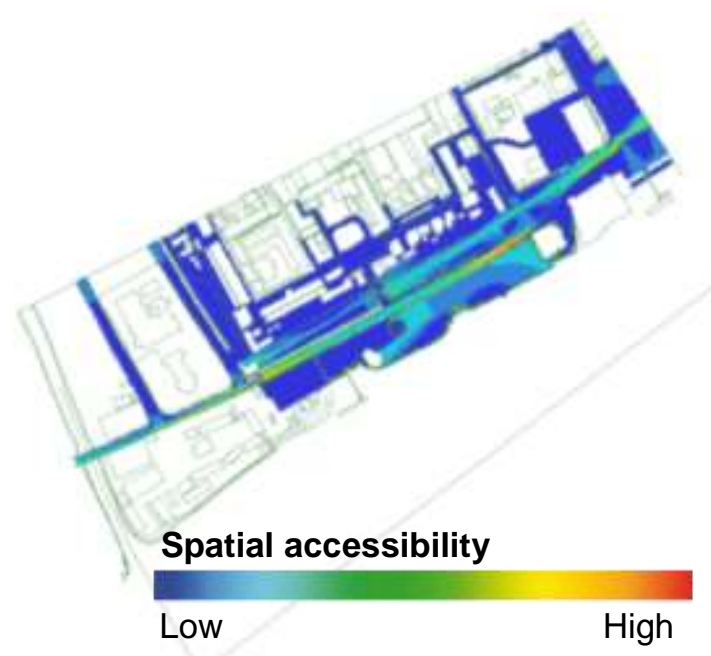

Gambar 16. Analisis grafik visual first and second movement

(sumber : analisis pribadi, 2017)

\section{ANALISIS SPACE SYNTAX VISIBILITY USULAN}

\section{Crowd Movement}

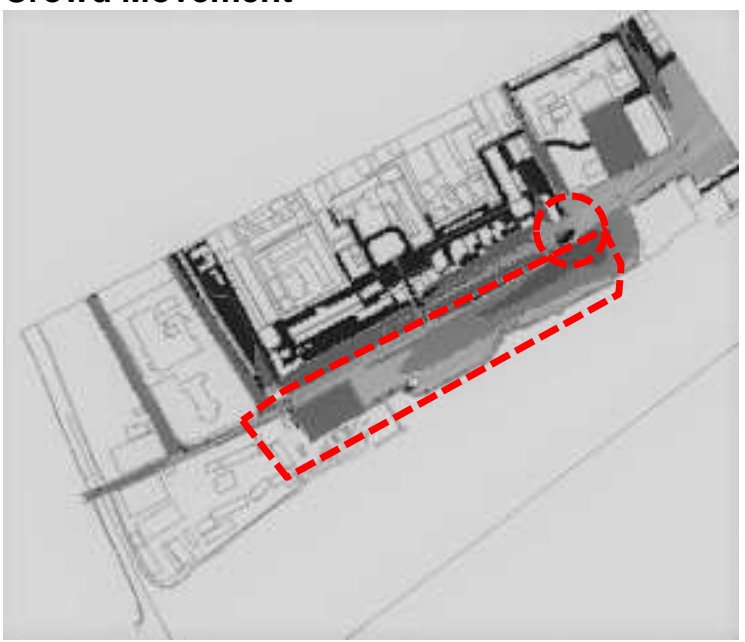

Gambar 17. Analisis space syntax visibility (sumber : analisis pribadi, 2017)

\section{Peta lokasi}

Perencanaan pengembangan kawasan BKB harus mempertimbangkan kesinambungan visibility agar menghasilkan ruang yang memiliki integrasi ruang yang baik. Tata letak bidang dan massa pengembangan kawasan harus dipertimbangkan dengan baik dan memperhatikan visibility dengan lingkungan sekitarnya.

\section{Analisis grafik visual crowd movement}

Aksesibilitas yang diusulkan pada kawasan BKB adalah perubahan elemen yang ada di pelataran BKB tersebut dengan membuat ruang yang memiliki elevasi lantai yang sama ataupun memiliki aksesibilitas yang menyatu agar tidak mengakibatkan ruang-ruang negatif di kawasan tersebut.

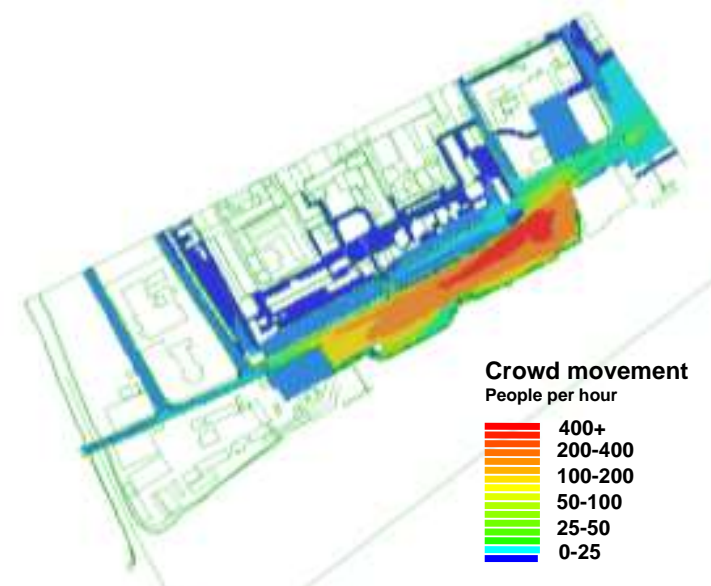

Gambar 18. Analisis grafik visual crowd movement (sumber : analisis pribadi, 2017)

\section{HIGH VISIBILITY}

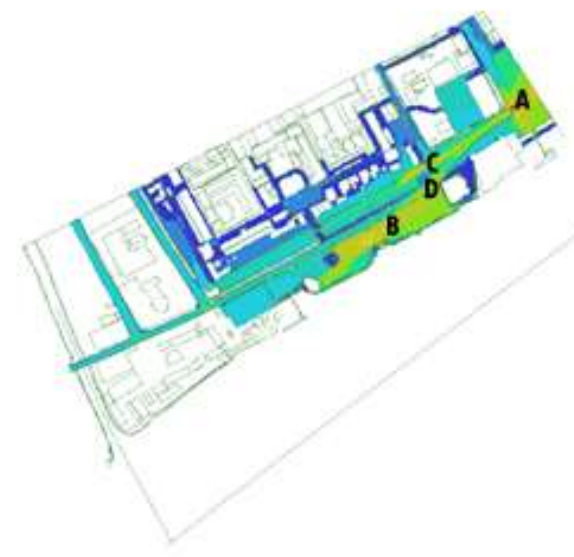

Gambar 19. High Visibility (sumber : analisis pribadi, 2017) 
Tabel 5. Kondisi High Visibility

\begin{tabular}{|c|c|c|}
\hline No & Foto & keterangan \\
\hline$A$ & & $\begin{array}{ll}\text { - } & \text { Ramai dilalui } \\
\text { pengunjung } \\
\text { - } \\
\text { Berpotensi } \\
\text { menjadi tempat } \\
\text { komersil }\end{array}$ \\
\hline$B$ & & $\begin{array}{l}\text { Menjadi tempat } \\
\text { berkumpul } \\
\text { Ramai baik } \\
\text { pengunjung dan } \\
\text { komersil }\end{array}$ \\
\hline $\mathrm{C}$ & & $\begin{array}{l}\text { Ramai dilalui } \\
\text { pengunjung. }\end{array}$ \\
\hline $\mathrm{D}$ & & $\begin{array}{l}\text { Ramai dilalui } \\
\text { pengunjung. } \\
\text { Tempat berkumpul }\end{array}$ \\
\hline
\end{tabular}

\section{LOW VISIBILITY}

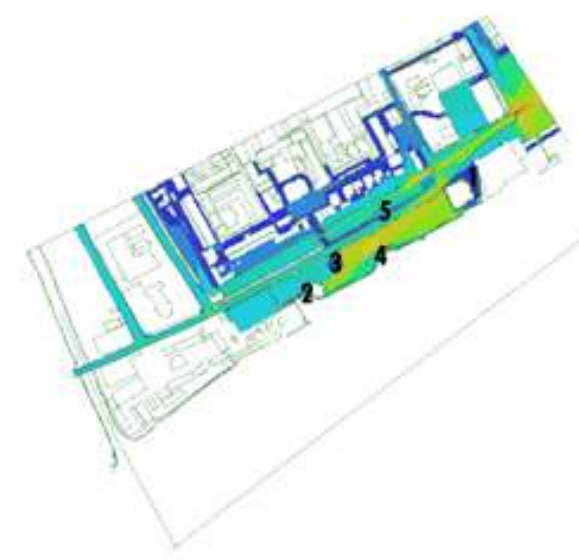

Gambar 20. Low Visibility

(sumber : analisis pribadi, 2017)

Tabel 5. Kondisi Low Visibility

\begin{tabular}{|l|l|l|}
\hline No & Foto & keterangan \\
\hline 1 & & Dijadiakan tempat \\
& & mojok \\
& & Sepi dan dihindari \\
& & Pengunjung \\
& & Menjadi ruang \\
& & negatif \\
\hline
\end{tabular}

\begin{tabular}{|c|c|c|}
\hline 2 & 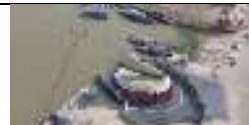 & $\begin{array}{ll}\text { - } & \text { Terdapat ruang mati } \\
\text { - } & \text { Dijadiakan tempat } \\
\text { mojok }\end{array}$ \\
\hline 3 & & $\begin{array}{l}\text { Bentuk tidak sesuai } \\
\text { dengan } \\
\text { peruntukannya } \\
\text { Bentuk memecah } \\
\text { sirkulasi ruang } \\
\text { - Sebagai ruang duduk } \\
\text { duduk }\end{array}$ \\
\hline 4 & 2 & $\begin{array}{l}\text { Komposisi ruang } \\
\text { diperuntukkan } \\
\text { sebagai pelabuhan } \\
\text { Tangga pelabuhan } \\
\text { banyak digunakan } \\
\text { sebagai tempat } \\
\text { duduk. }\end{array}$ \\
\hline 5 & & $\begin{array}{l}\text { Pembatas ruang } \\
\text { parkir dan jalan tidak } \\
\text { didesain untuk fungsi } \\
\text { ruang terbuka } \\
\text { Menjadi ruang } \\
\text { negatif dan sepi dari } \\
\text { pengunjung. }\end{array}$ \\
\hline
\end{tabular}

\section{Analisis Space Syntax axial eksisting}

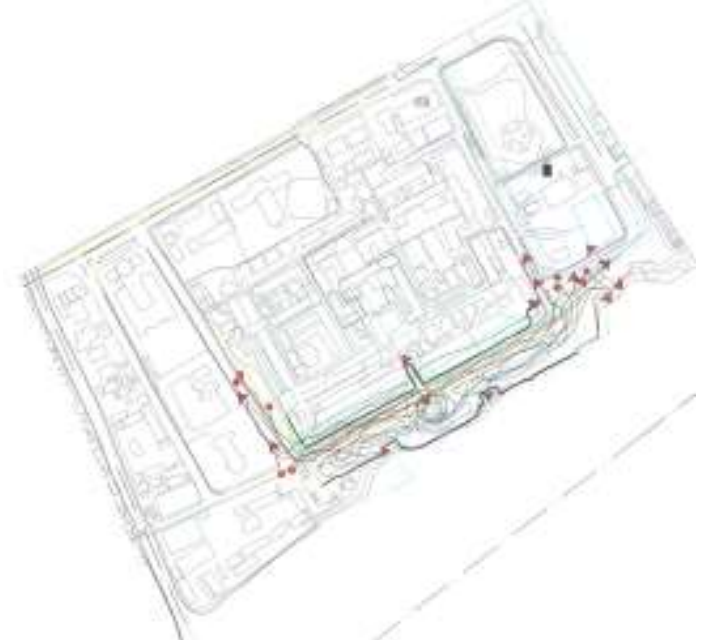

Gambar 21. Analisis Space Syntax Axial Existing

Peta lokasi (sumber : analisis pribadi, 2017)

Perencanaan pengembangan kawasan BKB harus mempertimbangkan kesinambungan visibility agar menghasilkan ruang yang memiliki integrasi ruang yang baik. Tata letak bidang dan massa pengembangan kawasan harus dipertimbangkan dengan baik dan memperhatikan visibility dengan lingkungan sekitarnya. 


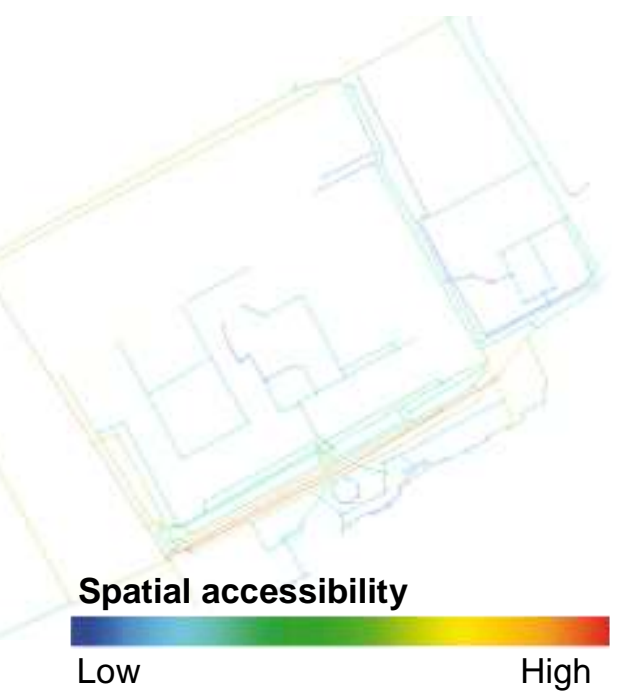

Gambar 22. Analisis Space Syntax (sumber : analisis pribadi, 2017)

Analisis axial menunjukkan adanya korelasi antara visibility eksisting kawasan benteng BKB

\section{Analisis Space Syntax isovist eksisting dan usulan}

Isovist eksisting

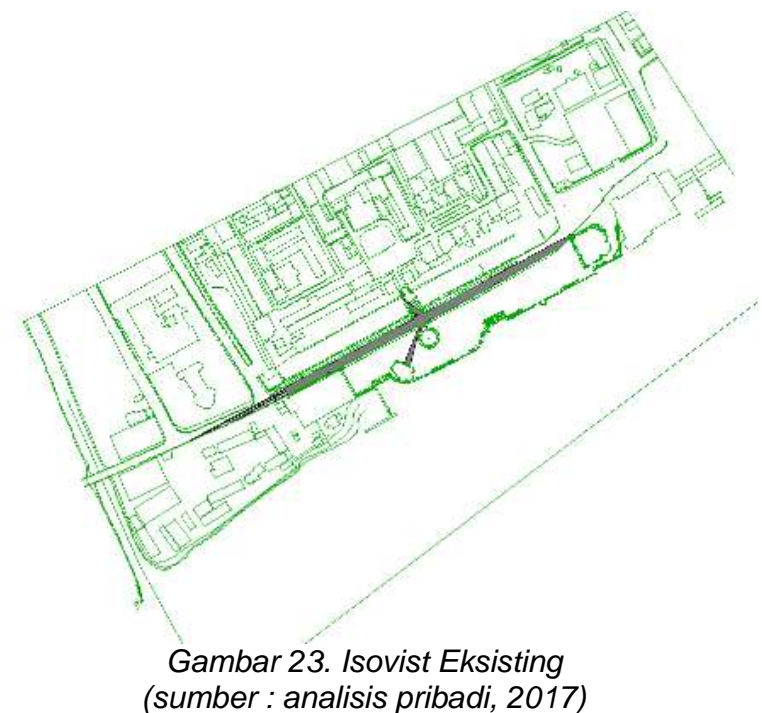

Analisis isovist eksisting space syntax digunakan untuk melihat kemudahan visual dari titik yang ditentukan oleh pengamat. Dalam kasus ini peneliti meletakan titik pengamatan di depan gerbang BKB dan terlihat di dalam hasil analisis tersebut bahwa adanya keterbatasan visual yang terbentuk. Dapat ditarik kesimpulan bahwa ruang terbuka BKB tersebut belum memiliki konektivitas ruang yang terhubung secara maksimal.
Isovist usulan ruang terbuka

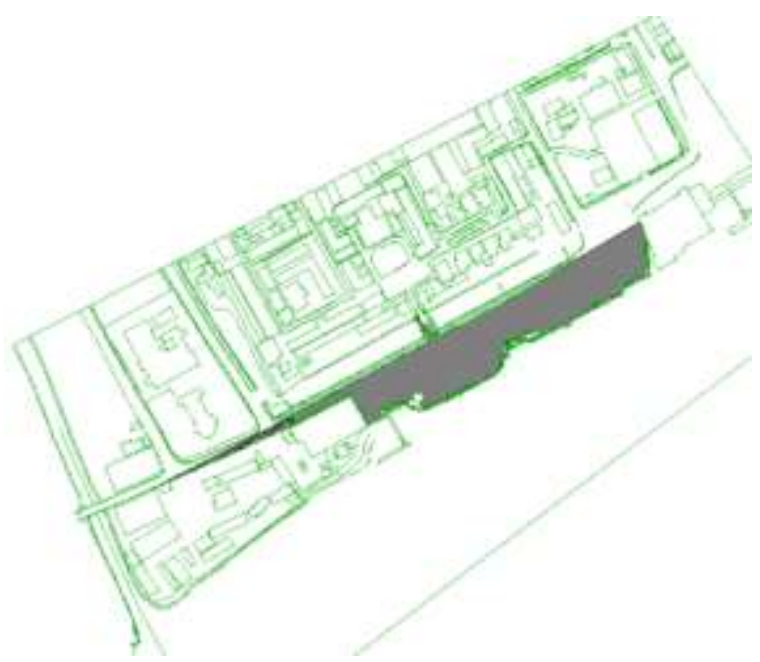

Gambar 24. Isovist usulan Ruang Terbuka (sumber : analisis pribadi, 2017)

Analisis isovist usulan space syntax digunakan untuk melihat kemudahan visual yang terbentuk dari titik yang ditentukan pengamat. Dalam kasus ini peneliti meletakkan titik pengamatan di depan gerbang BKB dan terlihat di dalam hasil analisis tersebut bahwa kemudahan visual yang terbentuk menunjukkan potensi yang sangat besar pada ruang terbuka BKB tersebut, namun dengan perencanaan yang kurang tepat dapat mengurangi kualitas dari ruang terbuka yang ada tersebut.

\section{INTERPRETASI RUANG}

Peta lokasi Spatial Logic

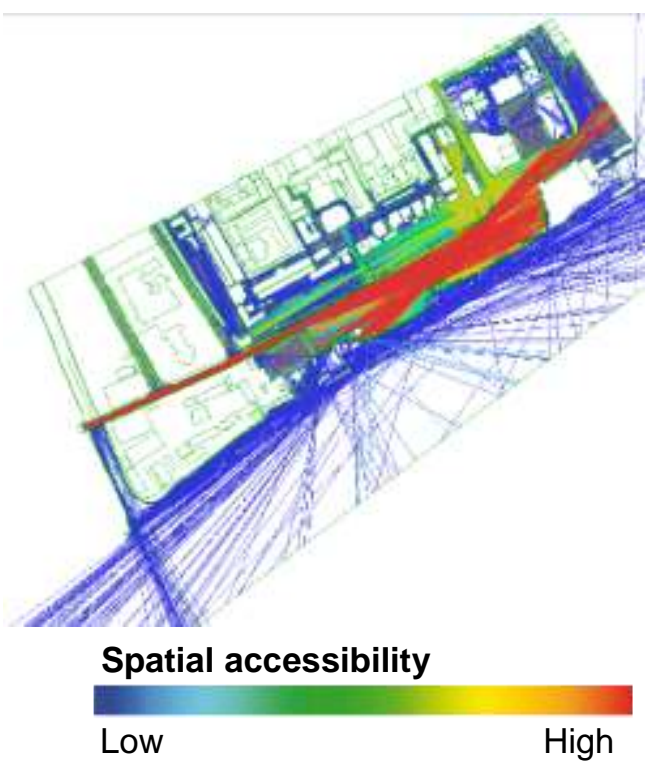

Gambar 25. Interpreatasi Ruang (sumber : analisis pribadi, 2017) 
Pada desain usulan spasial yang direncanakan oleh peneliti, dapat dilihat bahwa potensi yang ada pada ruang terbuka benteng kuto besak tersebut memliki visibility yang sangat baik dan terhubung dari semua arah. Pengembangan kawasan ruang terbuka tersebut harus memperhatikan aspek keselarasan dan kenyaman visual dari pengguna ruang terbuka tersebut sehingga tidak terbentuk nya ruang-ruang mati dan juga penempatan objek yang tidak selaras dengan ruang yang ada.

Dalam penelitian ini terlihat bahwa pemerintah tidak melakukan studi terhadap keadaan ruang terbuka yang ada sehingga adanya elemen ruang terbuka yang tidak sesuai penempatannya antara lain :

- Penambahan elemen landmark "iwak belido" dimana pedestal dari tugu tersebut terlihat bawha bentuk nya tidak sesuai dengan konfigurasi ruang yang ada.

- Elemen air mancur yang berada di tengah BKB juga memilii bentuk yang memotong keselarasan visual yang ada sehingga fungsinya dijadikan titik berhenti dan duduk-duduk dari para pengunjung.

- Panggung dan plataran BKB yang berbentuk tidak selaras dengan ruang terbuka BKB menciptakan ruangruang mati yang tidak dapat dimanfaatkan secara maksimal menjadi ruang yang kotor dan kumuh.

\section{DISKUSI}

Penelitian ini bertujuan untuk melihat karakteristik pergerakan manusia pada ruang terbuka kota. Kajian dilakukan dengan melihat eksisting pada awal peruntukan ruang terbuka tersebut, serta meilhat pengembangan yang dilakukan pada kawasan dengan menganalisis pergerakan yang terjadi pada ruang terbuka kawasan BKB tersebut. Tidak ada desain yang sempurna, tetapi dengan melakukan berbagai kajian pada eksisting, peneliti dapat menentukan desain ruang yang ideal pada kawasan BKB tersebut.

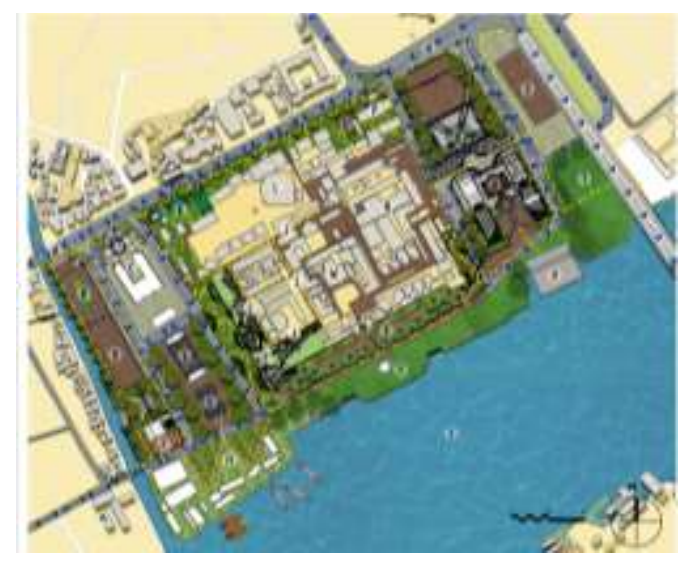

Gambar 26. Usulan Pengembangan Kawasan BKB (sumber : analisis pribadi, 2017)

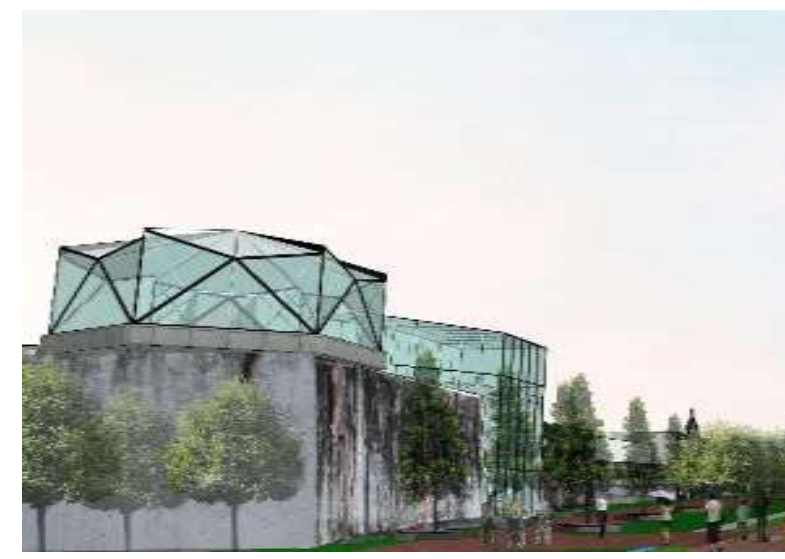

Gambar 27. Adaptif Reuse Kawasan BKB (sumber : analisis pribadi, 2017)

\section{KESIMPULAN}

Dengan perkembangan kota yang sangat pesat dan perubahan ruang kota yang seringkali dilakukan secara instan, dibutuhkan perencanaan jangka panjang dan simulasi terhadap ruang kota yang sudah ada. Dengan dasar pemikiran Benteng Kuto Besak yang menarik para investor seperti adanya rencana pemerintah untuk membangun sebuah tugu "Iwak Belida" yang mendapatkan reaksi dari pemerhati kota dan juga pemerhati heritage sehingga menimbulkan polemik yang berkepanjangan terhadap kualitas ruang kota tersebut. Dengan adanya anlisis mengenai pergerakan yang ada di dalam ruang kota tersebut diharapkan penelitian ini dapat memberikan kontribusi di bidang eksistensi ruang tersebut dan memberikan pilihan terhadap rencana pengembangan yang akan di lakukan di masa yang akan datang.

Perkembangan yang pesat di kota Palembang bukan berarti semua pembangunan fisik tersebut memberikan dampak yang baik. Di dalam kasus pengembangan kawasan 
Benteng Kuto Besak merupakan salah satu contoh pengembangan kawasan yang tidak disertai dengan perencanaan dan peruntukan dengan baik.

\section{DAFTAR PUSTAKA}

[1] Santun, D. I. M., 2011. Vinesia dari Timur : memaknai Produksi dan Reproduksi Simbolik kota Palembang dari Kolonial sampai Pascakolonial. Yogyakarta: Ombak.

[2] Subadyo, T., 2012. Optimasi Potensi Artefak Budaya dan Koridor Sungai Musi untuk Pengembangan Wisata Sejarah di Kota Palembang. Palembang, Unsri Press, pp. 17-24.

[3] UU no 26 Tahun 2007 tentang Penataan Ruang

[4] Anwar, W. F. F., 2013. Identification Of The Morphological Characteristic of Palembang Riverside Settlement. Johor: Faculty of Built Environment Universiti Teknologi Malaysia (unpublished dissertation).

[5] Hanson, B. H. a. J., 1984. The Social Logic of Space. Cambridge: Cambridge University Press.

[6] Hanafiah, D., 1989. Kuto Besak, Upaya Kesultanan Palembang Menegakkan Kemerdekaan. Palembang: Penerbit Masagung.

[7] Undang-Undang Nomor 11, 2010. Tahun 2010 Tentang Cagar Budaya.

[8] Sukamolson, S., 2010. Fundamental of Quantitative Research. Bangkok: Language Institute, Chulalangkorn University.

[9] Creswell, J. W., 2013. Research Design Qualitative, Quantitative and Mixed Method Approaches. S.I.SAGE publications

[10] Vujadinovic, M., 2016. A Typological Classification of Neighborhood Public Open Space : a case study of Novi Gradpodgrorica.. Facta Universtitatis series : Architecture and Civil Engineering, pp. 111-121.

[11] Stonor, T., 2011. Introduction to Space Syntax. Cambridge Massachusetts: Harvard University Graduate School of Design.
[12] Woolley, H., 2003. Urban Open Space. London: Spon Press.

[13] Shirvani, H., 1985. The Urban Design Process. New York: Van Nostrand.

[14] Tardin, R., 2013. System of Open Space. New York : Springer . 